\title{
Juvenile hormone titer and reproduction of Varroa jacobsoni in capped brood stages of Apis cerana indica in comparison to Apis mellifera ligustica
}

\author{
P Rosenkranz 1, ${ }^{\star}$, NC Tewarson 2, A Rachinsky 1, \\ A Strambi ${ }^{3}, \mathrm{C}$ Strambi ${ }^{3}$, W Engels 1
}

\footnotetext{
1 LS Entwicklungsphysiologie, Zoologisches Institut der Universität, Auf der Morgenstelle 28, D-72076 Tübingen, Germany;

${ }^{2}$ Department of Zoology, Ewing Christian College, Allahabad-211003, India; ${ }^{3}$ Laboratoire de Neurobiologie, CNRS, BP 71, F-13402 Marseille Cedex 9, France
}

(Received 24 November 1992; accepted 19 February 1993)

\begin{abstract}
Summary - The juvenile hormone $(\mathrm{JH})$ III hemolymph titer of late larval and early pupal stages as determined by radioimmunoassay (RIA) does not differ significantly in Apis cerana and Apis mellife$\mathrm{ra}$, particularly in freshly-sealed worker brood. In drone brood, slightly higher JH III hemolymph concentrations were recorded. These results do not agree with the hypothesis that reproduction of the parasitic bee mite Varroa jacobsoni is regulated by host-derived $\mathrm{JH}$. After checking over a thousand capped brood cells containing pupae, it was confirmed that in Apis cerana colonies fertitity of female mites is restricted to drone hosts.
\end{abstract}

Apis cerana indica / Apis mellifera ligustica / juvenile hormone titer / reproduction / Varroa jacobsoni

\section{INTRODUCTION}

In honey bees, juvenile hormone $(\mathrm{JH})$ has been studied mostly under aspects of caste development (Hartfelder, 1990; Rembold et al, 1992), control of fertility (Engels et al, 1990), and recently also polyethism regulation (Robinson, 1992).
Modern analytical techniques allow the determination of hemolymph titer (Rachinsky et al, 1990) and rate of synthesis (Rachinsky and Hartfelder, 1990) even in individual bees. Since in arthropods (Downer and Laufer, 1983) and also in acarids, ticks (Pound and Oliver, 1979; Connat et al, 1983) as well as mites (Oliver et al, 1985)

* Present address: Bayerische Landesanstalt für Bienenzucht, Burgbergstr 70, D-91054 Erlangen, Germany 
exogenous $\mathrm{JH}$ was generally found to affect reproduction, it was hypothesized that this hormone could also regulate oogenesis in the parasitic bee mite Varroa jacobsoni, and, in addition, that host-derived $\mathrm{JH}$ could be responsible for initiation of reproduction (Hänel, 1983). Particularly, a high $\mathrm{JH}$ III hemolymph titer in drone larvae of the early postcapping phase was considered to stimulate Varroa vitellogenesis in the original host species, Apis cerana, and likewise in worker larvae of the western honey bee, Apis mellifera (Hänel and Koeniger, 1986). Thus a low JH III titer in late 5 th instar worker larvae would be a resistant factor, restricting mite reproduction to drone brood.

However, in the only known case of varroatosis tolerance in Apis mellifera, the Africanized honey bees of Brazil (Engels et al, 1986), fertility of female mites in worker brood is also reduced (Ritter and De Jong, 1984) but was not found to be correlated with a low JH III hemolymph titer in worker larvae (Rosenkranz et al, 1990). These data already contradicted the hypothesis of a possible regulation of Varroa reproduction by the host's $\mathrm{JH}$. Because detailed $\mathrm{JH}$ III titer measurements were lacking in Apis cerana larvae, we analyzed hemolymph collected from Indian eastern honey bees together with Apis mellifera ligustica samples at the same study site. The fertility of Varroa females on drone and worker hosts of Apis cerana indica was also evaluated.

\section{MATERIALS AND METHODS}

Hemolymph samples were collected during the spring season, March 1991, from 4 colonies of Apis cerana indica kept in Newton hives (Tewarson et al, 1992) and 1 colony of Apis mellifera ligustica originating from the US in a Langstroth hive. All experimental colonies had 5 brood combs or more and were kept on the campus of Ewing Christian College, Allahabad, north India.
The time of brood cell capping was recorded with the help of transparent sheets. Subsequently larvae were at first taken at 6-h intervals, and later on less frequently. For each sample 40$120 \mu \mathrm{l}$ hemolymph from non-parasitized specimens were collected from 3-9 individuals, pooled, extracted with hexane, coded and stored at $-20^{\circ} \mathrm{C}$. After being transported to Europe on dry ice, $\mathrm{JH}$ III titer determinations were carried out after diol derivatization by radioimmunoassay (Strambi et al, 1981; Rosenkranz et al, 1990). In the Apis mellifera ligustica colony only little drone brood was present and was insufficient for sampling all required stages, probably due to high ambient temperatures.

In order to evaluate the actual reproduction of Varroa jacobsoni in the Apis cerana indica colonies, $\approx 1100$ capped brood cells containing pupae were opened and checked for female mites and their offspring. Because of severe brood infestation with Tropilaelaps clarae, no comparative data could be sampled from the Apis mellifera ligustica colony.

\section{RESULTS}

\section{Juvenile hormone hemolymph titer in postcapping stages of worker brood}

At the time of brood cell sealing in worker larvae, the $\mathrm{JH}$ III hemolymph titer was found to be low, ranging $<10 \mathrm{pmol} / \mathrm{ml}$ (fig 1a). However, soon after cell capping a steady increase was measured. Peak values of $70-100 \mathrm{pmol} / \mathrm{ml}$ were reached $\approx 30-48 \mathrm{~h}$ post cell operculation. There was not much variation in the different pool data sampled during that period after capping. On average, in 5th instar larvae of Apis cerana indica slightly higher $\mathrm{JH}$ concentrations were determined than in Apis mellifera ligustica, but the differences were statistically insignificant $(P>0.7$; Friedman test) even around the peak values. The duration of the $\mathrm{JH}$ III maximum was $\approx 24 \mathrm{~h}$, followed by a decrease in titer reached $\approx 96 \mathrm{~h}$ after cell capping, and again by another increase in the pupal stages (fig 1a). 


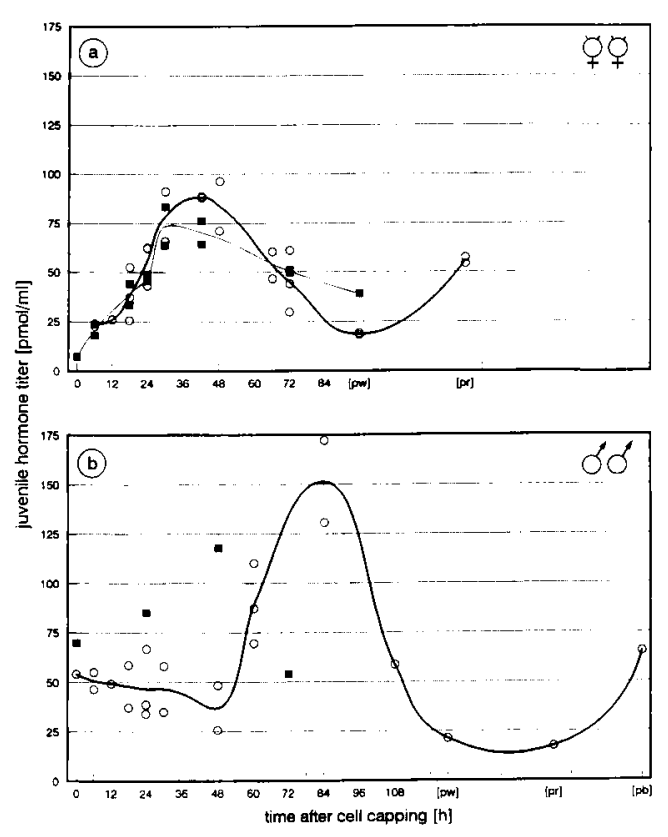

Fig 1. Hemolymph titer of juvenile hormone III in postcapping brood stages of eastern $(0,-$ Apis cerana indica) and western ( $\mathbf{\square},-$ Apis mellifera ligustica) honey bees. (a) $=$ workers, $(b)=$ drones. $\mathrm{pw}=$ white-eyed pupae, $\mathrm{pr}=$ red-eyed pupae, $\mathrm{pb}=$ brown-eyed pupae. Lines $=$ mean values the differences of which in (a) are not significant $(P>0.7$; Friedman test). The few data on drone brood of western honey bees (b) are insufficient for calculating a mean titer curve.

\section{Juvenile hormone hemolymph titer in postcapping stages of drone brood}

Within the first $48 \mathrm{~h}$ after brood cell operculation in drone larvae of Apis cerana indica the $\mathrm{JH}$ III hemolymph titer varied around $50 \mathrm{pmol} / \mathrm{ml}$ (fig 1b) which is clearly more than in worker larvae (fig 1a). An increase was observed with peak values up to 170 $\mathrm{pmol} / \mathrm{ml}$ only $\approx 84 \mathrm{~h}$ after cell capping. The subsequent decrease before the prepupal/ pupal moult and later reincrease resemble the titer pattern as determined for workers. The few available data for Apis mellifera ligustica drones fall into the range described for Apis cerana indica males. Whether in drone L5 larvae of the western honey bee the $\mathrm{JH}$ peak is reached a little earlier has not yet been determined.

\section{Fertility of Varroa jacobsoni in Apis cerana indica brood}

Because the first Varroa egg is usually laid $\approx 3 \mathrm{~d}$ after brood cell capping, an evaluation of the reproductivity of female mites at pupal stages of the host allows a distinct discrimination to be made between fertile and infertile parasite individuals. This was analyzed in several hundred Apis cerana indica worker and drone brood cells $\approx 1 \mathrm{wk}$

Table I. Brood infestation in Apis cerana indica and fertility of Varroa jacobsoni females (rate in bold type) on drone and worker hosts.

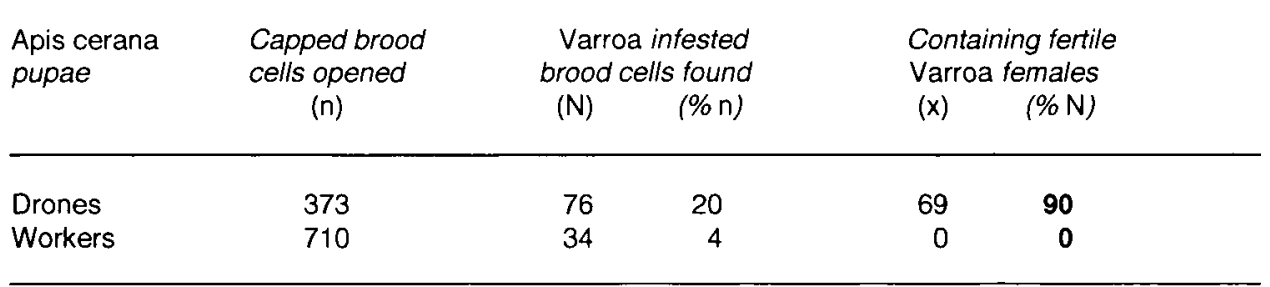


after sealing. The results (table I) demonstrate a much lower level of brood infestation in worker than in drone cells. Furthermore, no fertile Varroa female was detected in the worker brood at all, whereas most of the mites found in drone brood were reproducing.

\section{DISCUSSION}

From the point of view of development, it is not surprising that the $\mathrm{JH} \mathrm{III} \mathrm{hemolymph}$ titer was found to be almost identical in preimaginal stages of Apis cerana indica and $A$ mellifera ligustica. JH III titer data for Apis cerana obtained by radioimmunoassay (RIA) are presented here for the first time. Similar results have recently been reported for Apis mellifera carnica and Africanized bees (Rachinsky et al, 1990; Rosenkranz et al, 1990). All these data are in good agreement.

Little is known about JH III in drone development (Hartfelder et al, 1993). However, the data available on rates of $\mathrm{JH}$ synthesis in late larval and early pupal drones as well as the $\mathrm{JH}$ III hemolymph titer values reported here are a little higher but do not differ much from the worker data. Therefore, it is improbable that a hostderived $\mathrm{JH}$ stimulus enhances Varroa reproduction in drone brood. Particularly the time of the $\mathrm{JH}$ peak during the spinning L5 drone instar 3-4 d after capping of the cerana brood cells already coincides with the oviposition of the first Varroa egg and, consequently, occurs far too late to stimulate oocyte development in the first gonocycle. Furthermore, there is only 1 peak within $8 \mathrm{~d}$ after capping in the $\mathrm{JH}$ III titer as well as in $\mathrm{JH}$ III content (Rembold, 1987) and not 2, with the second occurring after $\approx 6-7 \mathrm{~d}$, as reported by Hänel and Koeniger (1986). An account of a RIAdetermined course of the $\mathrm{JH}$ III hemo- lymph titer in postcapping stages of drones has not been published previously, whereas such data are already known for workers and queens (Rachinsky et al, 1990). In both female castes of Apis mellifera carnica the JH III content has also been reported recently for the complete period of preadult development (Rembold et al, 1992) with similar worker values for all postcapping stages.

The regulation of metamorphosis and the involvement in sex- and caste-specific control of $\mathrm{JH} \mathrm{III} \mathrm{production} \mathrm{(Hartfelder} \mathrm{et}$ al, 1993) probably existed long before the splitting of the genus Apis occurred (Ruttner, 1988, 1992). The control of polymorphic patterns in the duration of the postcapping period in honey bees apparently allows some variation (Moritz, 1985), but this concerns the moment of cell operculation in particular and not the hormone titer peaks correlated with the initiation of metamorphosis and the switch from larval to prepupal-pupal developmental programs.

Consequently, species-specific differences in late 5th instar or prepupal JH III hemolymph titers are rather improbable as an adaptive character related to parasitization by Varroa jacobsoni. In fact, in newly capped worker larvae and prepupae of Apis cerana indica we found a JH III titer that was even a little higher than in immature Apis mellifera ligustica sampled at the same study site, and also in Apis mellifera carnica (Rachinsky et al, 1990) as well as in Africanized bees from Brazil (Rosenkranz et al, 1990). All these RIA-based data differ from the Galleria wax test values according to which the postcapping $\mathrm{JH}$ III hemolymph titer was described to be higher in Apis mellifera than in Apis cerana (Hänel and Koeniger, 1986). There is no explanation for this discrepancy.

Therefore, the oft-quoted hypothesis (Ramirez and Otis, 1986; Camazine, 1988; 
Ruttner, 1992) of a regulation of parasite reproduction by host-derived $\mathrm{JH}$ in case of the Varroa-Apis relationship is not supported by the hormone titers as measured here with a sensitive and accurate RIA (Strambi et al, 1981). Of course this does not concern the results obtained by $\mathrm{JH}$ application to Varroa females (Hänel, 1983; Hänel and Koeniger, 1988) which, however, Milani and Chiesa (1990) were unable to reproduce.

On the other hand, there is no doubt about the dependence of initiation of Varroa oogenesis on specific host conditions (Rosenkranz, 1990; Steiner, 1991; Rosenkranz and Stürmer, 1993; Steiner et al, 1993). Hemolymph of L5 instars capped less than $24 \mathrm{~h}$ earlier was found to stimulate mite egg development. However, in host larvae at this stage the $\mathrm{JH}$ III hemolymph titer is very low (Rachinsky et al, 1990; Rosenkranz et al, 1990; this paper). In any case, all the available evidence points towards the significance of inhibiting the fertility of female mites reproducing in worker brood as a natural resistance factor to varroatosis. This phenomenon is well documented both in the original host species, Apis cerana (Koeniger et al, 1981; Tewarson, 1987; Tewarson et al, 1992), and has been confirmed by the present study (table I). In the Africanized Apis mellifera scutellata hybrid biotype in Brazil (Ritter and De Jong, 1984; Rosenkranz et al, 1990) and hybrid colonies of Apis mellifera monticola and Apis mellifera ligustica (Thrybom and Fries, 1991) a similarly low rate of Varroa fertility was observed. However, the host factors responsible for influencing reproduction of the Varroa mite still remain to be detected.

\section{ACKNOWLEDGMENT}

This study was supported by a DAAD overseas research grant to $P$ Rosenkranz.
Résumé - Teneur en hormone juvénile et reproduction de Varroa jacobsoni dans le couvain operculé d'Apis cerana indica et d'Apis mellifera ligustica. À Allahabad (Inde du Nord), on a prélevé au printemps des échantillons d'hémolymphe dans du couvain operculé d'ouvrières et de mâles issu de 4 colonies d'Apis cerana indica et d'une colonie d'Apis mellifera ligustica. On a en outre ouvert plus de 1000 cellules de couvain renfermant des nymphes d'A $c$ indica pour vérifier la présence de Varroa jacobsoni, et on a noté si les femelles de Varroa s'étaient reproduites. Les échantillons d'hémolymphe ont été envoyés en Europe et leur teneur en hormone juvénile III $(\mathrm{JH})$ a été déterminée par méthode radio-immunologique.

Jusqu'à la mue nymphale, les teneurs en $\mathrm{JH}$ du couvain operculé d'ouvrières diffèrent peu chez les 2 races indica et ligustica. Celle des larves de l'abeille indienne est en moyenne un peu plus élevée que celle de l'abeille européenne (fig 1a). Dans le couvain de mâles, des teneurs en $\mathrm{JH}$ un peu plus élevées dans l'ensemble que chez les ouvrières (fig 1b) ont été mesurées après operculation. Les valeurs maximales se rencontrent le $2^{e} \mathrm{j}$ après l'operculation dans le couvain d'ouvrières et le $4^{\mathrm{e}} \mathrm{j}$ dans le couvain de mâles. Dans les 2 cas, la présence d'un pic était nette. Le moment où il se produit, ainsi que les différences spécifiques à la race et au sexe, ne rentrent pas en ligne de compte pour déclencher la reproduction de Varroa.

Chez $A c$ indica le parasitisme du couvain par Varroa a été contrôlé 1 semaine environ après l'operculation. Les cellules renfermaient déjà des nymphes. Le couvain de mâles était nettement plus parasité que celui d'ouvrières, conformément aux résultats antérieurs. Puisque les femelles de Varroa pondent leur premier œuf environ $3 \mathrm{j}$ après l'operculation, il était possible au moment du contrôle de différencier de façon sûre les acariens fertiles des non fer- 
tiles. Dans les cellules de mâles, presque toutes les femelles d'acariens s'étaient reproduites. En revanche dans les cellules d'ouvrières, pas un seul Varroa n'avait pondu (tableau I).

Ces données, en particulier celles relatives à l'évolution de la teneur en $\mathrm{JH}$ du couvain operculé chez l'abeille indienne et l'abeille européenne, sont en contradiction avec les résultats précédents, sur lesquels se fonde l'hypothèse souvent citée de la régulation de la reproduction de Varroa par la JH III présente dans l'hémolymphe d'abeilles (Hänel et Koeniger, 1986).

Apis cerana indica / Apis mellifera ligustica / hormone juvénile / reproduction / Varroa jacobsoni

\section{Zusammenfassung - Juvenilhormon-} Titer und Fortpflanzung von Varroa jacobsoni in verdeckelter Brut von Apis cerana indica im Vergleich zu Apis mellifera ligustica. In Allahabad (NordIndien) wurden im Frühjahr Hämolymphproben von verdeckelter Arbeiterinnenund Drohnenbrut in 4 Völkern von Apis cerana indica und 1 Volk von Apis mellifera ligustica gesammelt. Außerdem wurden über 1000 verdeckelte Brutzellen mit Puppen von Apis cerana indica geöffnet und auf Befall mit Varroa jacobsoni geprüft. Dabei wurde notiert, ob die Milbenweibchen sich fortgepflanzt hatten. Die Hämolymphproben wurden anschließend in Europa mittels Radioimmunoassay (RIA) auf ihren Gehalt an Juvenilhormon III $(\mathrm{JH})$ analysiert und daraus $\mathrm{JH}$-Titer der Hämolymphe berechnet.

Die so ermittelten JH-Titer von verdeckelter Arbeiterinnenbrut unterscheiden sich bei Apis cerana indica und Apis mellifera ligustica bis zur Puppenhäutung kaum, die Titer-Werte der Larven indischer Honigbienen liegen durchschnittlich sogar etwas über denen der europäischen (Abb 1a). Bei Drohnenbrut wurden nach dem Verdeckeln insgesamt leicht höhere $\mathrm{JH}$ Titer gemessen (Abb 1b) als bei Arbeiterinnen. Die Titer-Maxima traten bei Arbeiterinnenbrut am 2. und bei Drohnenbrut am 4. Tag nach dem Verdeckeln auf, in beiden Fällen war lediglich ein Peak ausgeprägt. Diese Zeitpunkte der JH-Peaks und ebenso die geringen Art- und Geschlechtsspezifischen Titerunterschiede kommen als Auslöser für die Milbenfortpflanzung nicht in Frage. Bei Apis cerana indica wurde der Milbenbefall von Brut etwa eine Woche nach dem Verdeckelungszeitpunkt kontrolliert. Die Zellen enthielten dann bereits Puppen. In Übereinstimmung mit früheren Befunden war die Drohnenbrut wesentlich stärker infiziert als die Arbeiterinnenbrut. Da Varroa-Weibchen das erste Ei ungefähr 3 Tage nach dem Verdeckeln ablegen, konnte zum gewählten Kontrollzeitpunkt sicher zwischen fruchtbaren und unfruchtbaren Milben unterschieden werden. In Drohnenzellen hatten sich fast alle Milbenweibchen fortgepflanzt. In Arbeiterinnenzellen dagegen hatte keine einzige Varroa-Milbe ein Ei gelegt (Tabelle I).

Die hier mitgeteilten Daten, insbesondere über Verlauf des JH-Titers in verdeckelter Brut sowohl bei der östlichen wie bei der westlichen Honigbiene, stehen im Widerspruch zu früheren Befunden, auf denen eine vielzitierte Hypothese über Steuerung der Varroa-Fortpflanzung durch $\mathrm{JH} \mathrm{III} \mathrm{aus} \mathrm{der} \mathrm{Bienenhämolymphe} \mathrm{basiert}$ (Hänel und Koeniger, 1986).

Apis cerana indica / Apis mellifera ligustica / Juvenilhormon / Fortpflanzung / Varroa jacobsoni

\section{REFERENCES}

Camazine S (1988) Factors affecting the severity of Varroa jacobsoni infestations on European and Africanized honey bees. In: Afri- 
canized Honey Bees and Bee Mites (Needham GR, Page RE, Delfinado-Baker M, Bowman $\mathrm{CE}$, eds) Ellis Horwood Ltd, Chichester, 444-451

Connat JL, Ducommun J, Diehl PA (1983) Juvenile hormone-like substances can induce vitellogenesis in the tick Ornithodoros moubata (Acarina: Argasidae). Int $J$ Invertebr Reprod 6, 285-294

Downer RGH, Laufer H (eds) (1983) Invertebrate Endocrinology. AR Liss, New York

Engels W, Gonçalves LS, Steiner J, Buriolla AM, Cavichio Issa MR (1986) Varroa-Befall von Carnica-Völkern in Tropenklima. Apidologie 17, 203-216

Engels $W$, Kaatz $H$, Zillikens A, Simoes ZLP, Trube A, Braun R, Dittrich F (1990) Honey bee reproduction: vitellogenin and castespecific regulation of fertility. Adv Invertebr Reprod 5, 495-502

Hänel $\mathrm{H}$ (1983) Effect of JH III on the reproduction of Varroa jacobsoni. Apidologie 14, 137 142

Hänel $H$, Koeniger $N$ (1986) Possible regulation of the reproduction of the honey bee mite Varroa jacobsoni (Mesostigmata: Acari) by a host's hormone: juvenile hormone III. J Insect Physiol 32, 791-798

Hartfelder K (1990) Regulatory steps in caste development of eusocial bees. In: Social Insects, An Evolutionary Approach to Castes and Reproduction (Engels W, ed) Springer, Heidelberg, 245-264

Hartfelder K, Tozetto S de O, Rachinsky A (1993) Sex-specific developmental profiles of juvenile hormone synthesis in honey bee larvae. Roux's Arch Dev Biol 202, 176-180

Koeniger $\mathrm{N}$, Koeniger $\mathrm{G}$, Wijayagunasekara NHP (1981) Beobachtungen über die Anpassung von Varroa jacobsoni an ihren natürlichen Wirt Apis cerana in Sri Lanka. Apidologie 12, 37-40

Milani N, Chiesa F (1990) Some stimuli inducing oviposition in Varroa jacobsoni Oud. In: Proceedings of the International Symposium on Recent Research on Bee Pathology (Ritter W, Van Laere O, Jacobs F, De Wael L, eds) Apimondia, Ghent, 27-33

Moritz RFA (1985) Heritability of the postcapping stage in Apis mellifera and its relation to varroatosis resistance. $J$ Hered 76, 267-270
Oliver JH Jr, Pound JM, Severino G (1985) Evidence of a juvenile-hormone-like compound in the reproduction of Dermanyssus gallinae (Acari: Dermanyssidae). J Med Entomol 22, 281-286

Pound JM, Oliver JH Jr (1979) Juvenile hormone: evidence of its role in the reproduction of ticks. Science 206, 355-357

Ramirez BW, Otis GW (1986) Developmental phases in the life cycle of Varroa jacobsoni, an ectoparasitic mite on honeybees. Bee World 67, 92-97

Rachinsky A, Strambi C, Strambi A, Hartfelder K (1990) Caste and metamorphosis: hemolymph titers of juvenile hormone and ecdysteroids in last instar honeybee larvae. Gen Comp Endocrinol 79, 31-38

Rachinsky A, Hartfelder K (1990) Corpora allata activity, a prime regulating element for castespecific juvenile hormone titre in honeybee larvae (Apis mellifera carnica). J Insect Physiol 36, 189-194

Rembold $\mathrm{H}$ (1987) Caste differentiation of the honeybee - fourteen years of biochemical research at Martinsried. In: Chemistry and Biology of Social Insects (Eder J, Rembold $\mathrm{H}$, eds) Peperny, Munich, 3-15

Rembold H, Czoppelt C, Grüne M, Lackner B, Pfeffer J, Woker E (1992) Juvenile hormone titers during honey bee embryogenesis and metamorphosis. In: Insect Juvenile Hormone Research (Mauchamp B, Couillaud F, Baehr JC, eds) INRA, Paris, 37-43

Ritter W, De Jong D (1984) Reproduction of Varroa jacobsoni Oud in Europe, the Middle East and tropical South America. $Z$ Angew Entomol 98, 55-57

Robinson GE (1992) Regulation of division of labor in insect societies. Annu Rev Entomo/37, 637-665

Rosenkranz P (1990) Der Einfluß larvaler Bienenhämolymphe auf die Fertilität von Varroa jacobsoni in europäischen und afrikanisierten Bienenvölkern. Apidologie 21, 370-372

Rosenkranz P, Rachinsky A, Strambi A, Strambi C, Ropstorf P (1990) Juvenile hormone titer in capped worker brood of Apis mellifera and reproduction in the bee mite Varroa jacobsoni. Gen Comp Endocrinol 78, 189-193

Rosenkranz P, Stürmer M (1993) Ernährungsabhängige Fertilität der Varroa 
Weibchen in Arbeiterinnenbrut von Apis mellifera carnica und Apis mellifera capensis. In: Proc 1st Polish-German Symp Progress in Varroatosis Research. Stettin, Poland (in press)

Ruttner F (1988) Biogeography and Taxonomy of Honeybees. Springer, Berlin

Ruttner $F$ (1992) Naturgeschichte der Honigbienen. Ehrenwirth, Munich

Steiner J (1991) Oogenese und Embryogenese während des ersten Gonozyklus von Varroa jacobsoni. Apidologie 22, 460-462

Steiner J, Dittmann F, Rosenkranz P, Engels W (1993) Interrelation between reproduction of the honey bee (Apis mellifera carnica) parasitic mite (Varroa jacobsoni) and preimaginal host development during the first gonocycle. Invertebr Reprod Dev 23, in press
Strambi C, Strambi A, de Reggi ML, Hirn MH, Delaage MA (1981) Radioimmunoassay of insect juvenile hormones and of their diol derivatives. Eur J Biochem 118, 401-406

Tewarson NC (1987) Use of host hemolymph proteins, seasonal reproduction and a hypothesis on nutritional imprinting in the honey bee mite, Varroa jacobsoni, on Apis mellifera and Apis cerana. In: Chemistry and Biology of Social Insects (Eder J, Rembold H, eds) $J$ Peperny, Munich, 688-689

Tewarson NC, Singh A, Engels W (1992) Reproduction of Varroa jacobsoni in colonies of Apis cerana indica under natural and experimental conditions. Apidologie 23, 161-171

Thrybom B, Fries I (1991) Development of infestations by Varroa jacobsoni in hybrid colonies of Apis mellifera monticola and Apis mellifera ligustica. J Apicult Res 30, 151-155 